Grand Valley State University

ScholarWorks@GVSU

Winter 12-2003

\title{
Left-sided Directional Bias of Cloacal Contacts During House Sparrow Copulations
}

\author{
Karen B. Nyland \\ Grand Valley State University \\ Michael P. Lombardo \\ Grand Valley State University, lombardm@gvsu.edu \\ Patrick A. Thorpe \\ Grand Valley State University
}

Follow this and additional works at: https://scholarworks.gvsu.edu/biopeerpubs

Part of the Behavior and Ethology Commons, Biology Commons, Poultry or Avian Science Commons, and the Zoology Commons

\section{ScholarWorks Citation}

Nyland, Karen B.; Lombardo, Michael P.; and Thorpe, Patrick A., "Left-sided Directional Bias of Cloacal Contacts During House Sparrow Copulations" (2003). Peer Reviewed Publications. 7.

https://scholarworks.gvsu.edu/biopeerpubs/7 
characteristics, such as the Lesser Rhea (Pterocnemia pennata) or some tinamous species, might show a similar female behavior. Further studies are necessary to test this hypothesis and to clarify the adaptive function of such social behavior.

\section{ACKNOWLEDGMENTS}

We thank J. Boote and H. Martínez Guerrero for allowing us to conduct this study at Estancias Los Yngleses and La Clementina, respectively, and R. Paso, J. Flores, and A. Guzmán for their collaboration. We thank P. Llambías, V. Ferretti, W. Piper, D. Lank, and D. Mock for providing useful comments on earlier versions of this manuscript. M. Beade from Fundación Vida Silvestre Argentina provided logistical support during the study.

\section{LITERATURE CITED}

Andersson, M. 1994. Sexual selection. Princeton Univ. Press, Princeton, New Jersey.

Astley, H. D. 1907. Polyandry in the Rhea. Avic. Mag. 5:267-268.

Bertram, B. C. R. 1992. The Ostrich communal nesting system. Princeton Univ. Press, Princeton, New Jersey.

BRUNING, D. F. 1974. Social structure and reproductive behavior of the Greather Rhea. Living Bird 13: 251-294.

Coddington, C. L. And A. CockBurn. 1995. The mating system of free living Emus. Aust. J. Zool. 43: $365-372$.

FERnÁNDEZ, G. J. 1998. Ecología reproductiva del ñandú común, Rhea americana. Ph.D diss., Univ. of Buenos Aires, Buenos Aires, Argentina.

Fernández, G. J. ANd J. C. Reboreda. 1998. Effect of clutch size and time of the breeding season on the reproductive success of Greater Rheas, Rhea americana. Auk 115:340-348.

Foster, M. S. 1977. Odd couples in manakins: a study of social and cooperative breeding in Chriroxiphia linearis. Am. Nat. 111:845-853.

FosTer, M. S. 1981. Cooperative behavior and social organization in the Swallow-tailed Manakin (Chriroxiphia caudata). Behav. Ecol. Sociobiol. 9:167-177.

Höglund, J. and R. V. Alatalo. 1995. Leks. Princeton Univ. Press. Princeton, New Jersey.

Hugie, D. M. And D. B. Lank. 1997. The resident's dilemma: a female choice model for the evolution of alternative mating strategies in lekking male Ruffs (Philomonachus pugnax). Behav. Ecol. 8: 218-225.

JENNI, D. 1974. Evolution of polyandry in birds. Am. Zool. 14:129-144.

Leirman, D. S. 1959. Hormonal responses to external stimuli in birds. Ibis 101:478-497.

MCDONALD, D. B. 1989. Correlates of male mating success in a lekking bird with male-male cooperation. Anim. Behav. 37:1007-1022.

McDonald, D. B. And W. K. Potts. 1994. Cooperative display and relatedness among males in a lekmating bird. Science 266:1030-1032.

Nicholls, E. H., T. Burke, and T. R. Birkhead. 2001. Ejaculate allocation by male Sand Martins, Riparia riparia. Proc. R. Soc. London B. Ser. 268: 1265-1270.

OrING, L. W. 1982. Avian mating systems. Pp. 1-92 in Avian biology, vol. 6 (D. S. Farner, J. R. King, and K. C. Parkes, Eds.). Academic Press, New York.

RAIKow, R. J. 1969. Sexual and agonistic behavior of the Common Rhea. Wilson Bull. 81:196-202.

RobBINS, M. B. 1985. Social organization of the Bandtailed Manakin (Pipra fasciicauda). Condor 87: 449-456.

Soriano, A. 1991. Río de la Plata Grasslands. Pp. 367-407 in Ecosystems of the world, vol. 8: natural grasslands (R. T. Coupland, Ed.). Elsevier, Amsterdam, Netherlands.

VehrenCAMP, S. L. 2000. Evolutionary routes to jointfemale nesting in birds. Behav. Ecol. 11:334-344.

Westneat, D. F., L. A. McGraw, J. M. Fraterrigo, T. R. BIRKHEAD, ANI F. FI.ETCHER. 1998. Patterns of courtship behavior and ejaculate characteristics in male Red-winged Blackbirds. Behav. Ecol. Sociobiol. 43:161-171.

Wilson Bull., 115(4), 2003, pp. 470-473

\title{
Left-sided Directional Bias of Cloacal Contacts During House Sparrow Copulations
}

\author{
Karen B. Nyland, ${ }^{1,2}$ Michael P. Lombardo, ${ }^{1,3}$ and Patrick A. Thorpe
}

ABSTRACT.-Most female birds have only a left ovary and associated oviduct. The entry to the oviduct is on the left side of the urodeum of the cloaca. This arrangement may favor males that mount females from the left during copulation if it results in sperm being placed closer to the opening of the oviduct. Therefore, 
we predicted a left-sided directional bias of cloacal contacts during House Sparrow (Passer domesticus) copulations. Cloacal contacts from the left outnumbered those from the right 74 to $25(3: 1)$ during 25 bouts of copulation at 11 House Sparrow nests. While this pattern suggests that a left-sided bias in mounting by males during copulation may be related to the asymmetry of the female reproductive tract, it also might be related to brain lateralization. Received 14 May 2003, accepted 15 August 2003.

In most species, female birds have only a left ovary and associated oviduct. The entry to the oviduct is on the left side of the urodeum of the cloaca (King 1981). Interestingly, the erect phallus bends to the left (King 1981, Lake 1981), matching the asymmetry of the female reproductive tract in the approximately $3 \%$ of bird species that have an intromittent organ (e.g., ratites and anseriformes; Lake 1981, Briskic and Montgomerie 1997).

The lack of an obvious intromittent phallus would seem to make it more difficult for male passerines than for ratites or anseriforms to deposit semen near the oviduct (Briskie and Montgomerie 1997). However, the semenemitting papilla that extrudes from the urodeum of the male cloaca in some passerines might act as a phallus (Wolfson 1954, 1960; Birkhead et al. 1991; Mulder and Cockburn 1993; Birkhead and Hoi 1994; Lombardo 2001 ) facilitating the placement of semen near the oviduct and thereby increasing the probability of successful fertilization (Biellier et al. 1961, Holleman and Biellier 1976). It also may be more difficult for females to eject semen (Davies 1983) deposited directly into or near the opening of the oviduct.

The anatomical asymmetry of female reproductive tracts also could favor male behavioral adaptations during copulation. For example, males that mount females from the left may be favored if doing so results in ejaculates being placed closer to the oviduct (Petersen et al. 2001). For example, Gerhardt (1933, in King 1981) observed male Ostriches (Struthio camelus) mounting females from the left and

\footnotetext{
' Dept. of Biology, Grand Valley State Univ., Allendale, MI 49401, USA.

2 Current address: 1505 1/2 Main St., Lafayette, IN 47901, USA.

${ }^{3}$ Corresponding author; e-mail: lombardm $\left({ }^{(}\right)$gvsu.edu
}

related this behavior to the asymmetry of the female reproductive tract. Cloacal contacts from the left outnumbered those from the right by 3:1 during Tree Swallow (Tachycineta bicolor) copulations consistent with the "directional bias in mounting" hypothesis (Petersen et al. 2001). We examined the generality of the directional bias in mounting hypothesis to birds without intromittent organs by determining the left-right pattern of cloacal contacts during House Sparrow (Passer domesticus) copulations.

\section{METHODS}

We observed House Sparrow copulations between 06:30 and 09:00 EST each day from 30 April to 24 May 2002. The sparrows bred in wooden nest boxes that were arranged in a grid in an old field or mounted on utility poles along roadways on the campus of Grand Valley State Univ., Ottawa County, Michigan $\left(42^{\circ} 57^{\prime} \mathrm{N}, 85^{\circ} 53^{\prime} \mathrm{W}\right)$. We observed House Sparrows from the inside of parked vehicles and changed locations every $30-45 \mathrm{~min}$ to ensure that we observed as many active nests as possible each day. During observations, one field assistant transcribed the observations made by others.

House Sparrow copulations occur frequently and in conspicuous locations, and are easy to detect because they often are preceded by easily recognizable male and female precopulatory displays (Lowther and Cink 1992). Male House Sparrows attempted copulations by trying to land on the backs of females in order to make cloacal contact. Following Petersen et al. (2001), we (1) scored a copulation attempt as successful when we observed a male land on a female's back and both birds twisted their tails so that their cloacae made contact and (2) recorded whether each cloacal contact was made from the right or left side of the female's body. It was easy to determine the side from which males mounted females because females bent their tails in the direction opposite that of the male mounting position. Females rejected copulation attempts by either keeping their tails down, which prevented males from make cloacal contact, or by flying away.

We used SPSS ver. 10.0 for Windows (SPSS, Inc. 2002) to examine the data for normality and used parametric and nonparametric 
statistical tests to analyse data where appropriate.

\section{RESULTS}

We observed 99 cloacal contacts occurring during 25 bouts of copulation at 11 nest boxes (mean $=2.27 \pm 1.35 \mathrm{SD}$ bouts of copulation per nest box; range 1-5). Cloacal contacts per bout ranged from $1-11$ (mean $=3.96 \pm 3.31$ $\mathrm{SD}, n=25$ bouts). No matter how the data were partitioned, cloacal contacts from the left outnumbered those from the right. During the first bout of copulation we observed at each nest box (1) initial cloacal contacts from the left outnumbered those from the right seven to two $(78 \%$; we did not record the direction of the first cloacal contact at two boxes), (2) the total number of cloacal contacts from the left outnumbered those from the right 30 to 6 $\left(83 \% ; \chi^{2}=16.00\right.$, df $\left.=1, P<0.001\right)$, (3) the proportion of contacts from the left (mean $=$ $0.78 \pm 0.32 \mathrm{SD}$ ) was significantly greater than that from the right (mean $=0.22 \pm 0.32 \mathrm{SD}$; paired $t=2.94$, df $=10, P=0.015$ ), (4) the total number of contacts from the left outnumbered those from the right at nine boxes $(82 \%$; sign test, $P=0.02$ ), and (5) at six boxes $(55 \%)$ all cloacal contacts were from the left. During 25 bouts of copulation, the total number of cloacal contacts from the left outnumbered those from the right 74 to $25(74.7 \%)$.

\section{DISCUSSION}

House Sparrow copulations had the same left-sided directional bias in mounting as observed in Tree Swallows (Petersen et al. 2001), suggesting that this pattern might be common in birds without intromittent organs. Petersen et al. (2001) discussed several ways that a left-sided directional bias of cloacal contacts could reflect manifestations of male and female reproductive strategies and thus be adaptive. Similarly, some herpetologists (Crews 1978, Tokarz 1988, Tokarz and Slowinski 1990, Shine et al. 2000) have argued that some squamate reptiles alternately use each side of their hemipenis during copulation as a behavioral adaptation to sperm competition.

Contrary to the prediction of the directional bias in mounting hypothesis, American Avocets (Recurvirosta americana) and Blacknecked Stilts (Himantopus mexicanus), charadriiforms that lack intromittent organs, each showed a right-sided directional bias in mounting behavior (Sordahl 2001). A directional bias in mounting in birds need not be solely related to the asymmetry of the female reproductive tract and sperm competition; it also could be related to brain lateralization (Vallortigara et al. 1999). A variety of studies (e.g., Güntürkün and Kesch 1987, Güntürkün et al. 2000) suggest that brain lateralization directly affects avian behavior through the use of the lateral field of the eye contralateral to the brain hemisphere that controls that behavior (Vallortigara et al. 1999). Studies of eye laterality in passerines suggest a right eye preference for object-specific cues and a left eye preference for spatial cues (Clayton and Krebs 1994). Furthermore, the left eye appears to be more reactive to "emotionally charged" stimuli (Vallortigara 2000). Perhaps the left-sided directional bias in mounting in swallows and sparrows is related to a left eye preference for (1) the spatial skills required for the balance necessary for successful copulation and (2) reactions to the "exciting" stimulus of a female soliciting copulation. Brain lateralization may be the proximate mechanism underlying the ultimate explanation for the left-sided directional bias in mounting observed in Tree Swallows and House Sparrows. Further study of this question is required because laterality in eye use may differ even in closely related species; Dark-eyed Juncos (Junco hyemalis) and American Tree Sparrows (Spizella arborea) favor their right and left eye, respectively, when scanning for predators (Franklin and Lima 2001).

Differentiating between these nonmutually exclusive explanations will require careful observations of the anatomical mechanics of avian copulation and determining (1) whether male mounting direction in birds influences the probability of fertilization; (2) if other bird species show a directional bias during mounting, and if so, whether the directional bias is related to phylogeny; and (3) the role of brain lateralization in bird hehavior.

\section{ACKNOWLEDGMENTS}

M. Czarnowski and H. W. Power helped in developing some of the ideas in this paper. An e-mail to MPL from G. Villortigara suggested hypotheses we had not previously considered. J. Briskie, A. E. Mur- 
phy, and K. Smith provided some useful comments on a previous version of the manuscript. M. Czarnowski, M. Eggerman, and T. Weinstein assisted us in the field. A Summer Undergraduate Research Program award to the authors from the Science and Mathematics Div. and the Dept. of Biology at Grand Valley State Univ. supported this research. The Institutional Animal Care and Use Committee of Grand Valley State Univ. approved the research presented here.

\section{LITERATURE CITED}

Biellier, H. V., R. Paschange, and M. Funk. 1961. Effect of depth of insemination on fertility of Broad-breasted Bronze Turkey hens. Poultry Sci. 40:1379.

Birkhead, T. R., B. J. Hatchwell, and N. B. Davies. 1991. Sperm competition and the reproductive organs of the male and female Dunnock Prunella modularis. Ibis 133:306-311.

BIRKHEAD, T. R. ANI H. Hol. 1994. Reproductive organs and mating strategies of the Bearded Tit Panurus biarmicus. Ibis 136:356-360.

Briskie, J. V. And R. Montgomerie. 1997. Sexual selection and the intromittent organ of birds. J. Avian Biol. 28:73-86.

Clayton, N. Anis J. R. Krebs. 1994. Memory for spatial and object-specific cues in food-storing and non-storing birds. J. Comp. Physiol. A 174:371 379.

Crews, D. 1978. Hemipene preference: stimulus control of male mounting behavior in the lizard Anolis carolinensis. Science 199:195-196.

DAvits, N. B. 1983. Polyandry, cloaca-pecking and sperm competition in Dunnocks. Nature (Lond.) 302:334-336.

FrANKLIN, W. E. AND S. L. LimA. 2001. Laterality in avian vigilance: do sparrows have a favourite eye? Anim. Behav. 62:879-885.

Guntürkün, O., B. Diekamp, M. Mannis, F. NottelmanN, H. Prior, A. Schwarz, and M. Skiba. 2000. Asymmetry pays: visual lateralization improves discrimination success in pigeons. Curr. Biol. 10:1079-1081.

Güntürkün, O. AND S. Kesch. 1987. Visual lateralization during feeding in pigeons. Behav. Neurosci. 101:433-435.

Holleman, K. A. ANd H. V. Biellier. 1976. Importance of oviduct relaxation in artificial insemination of turkeys. Poultry Sci. 55:452-453.

KING, A. S. 1981. Cloaca. Pp. 107-148 in Form and function in birds, vol. 2 (A. S. King and J. McLelland, Eds.). Academic Press, New York.

LAKE, P. E. 1981. Male genital organs. Pp. 1-61 in Form and function in birds, vol. 2 (A. S. King and J. McLelland, Eds.). Academic Press, New York.

LOMBARIO, M. P. 2001. Individual and seasonal variation in the external genitalia of male Tree Swallows. Auk 118:789-795.

Lowther, P. E. And C. L. Cink. 1992. House Sparrow (Passer domesticus). No. 12 in The birds of North America (A. Poole, P. Stettenheim, and F. Gill, Eds.). Academy of Natural Sciences, Philadelphia, Pennsylvania, and the American Ornithologists' Union, Washington, D.C.

Mulder, R. A. And A. Cockburn. 1993. Sperm competition and the reproductive anatomy of male Superb Fairy Wrens. Auk 1 10:588-593.

Petersen, A. D., M. P. Lombardo, and H. W. Power. 2001. Left-sided directional bias of cloacal contacts during Tree Swallow copulations. Anim. Behav. 62:739-741.

Shine, R., M. M. Olsson, M. P. Lemaster, I. T. MoOre, AND M. T. MASON. 2000. Are snakes right-handed? Asymmetry in hemipenis size and usage in gartersnakes (Thamnophis sirtalis). Behav. Ecol. 11:411-415.

SORDAHL, T. A. 2001. Copulatory behavior of American Avocets and Black-necked Stilts. Auk 118: $1072-1076$.

SPSS, INC. 2002. SPSS for Windows, ver. 10.0. SPSS, Inc., Chicago, Illinois.

TOKARZ, R. R. 1988. Copulatory behaviour of the lizard Anolis sagrei: alternation of hemipenis use. Anim. Behav. 36:1518-1524.

TOKARZ, R. R. AND J. B. SLOWINSKI. 1990. Alternation of hemipenis use as a behavioural means of increasing sperm transfer in the lizard Anolis sagrei. Anim. Behav. 40:374-379.

VAllortigarA, G. 2000. Comparative neurophysiology of the dual brain: a stroll through animals' left and right perceptual worlds. Brain and Lang. 73: $189-219$.

Vallortigara, G., L. J. Rogiers, ani) A. Bisazza. 1999. Possible evolutionary origins of cognitive brain lateralization. Brain Res. Rev. 30:164-175.

WOLFSON, A. 1954. Notes on the cloacal protuberance, seminal vesicles, and a possible copulatory organ in male passerine birds. Bull. Chicago Acad. Sci. 10:1-23.

WOLFSON, A. 1960. The ejaculate and the nature of coition in some passerine birds. Ibis 102:124-125. 